\title{
Hybrid Concept Analysis of Self-Management Support: School Nurses Supporting Students with Psychogenic Nonepileptic Seizures
}

$$
2021
$$

Andrea Tanner, Jane von Gaudecker, Janice Buelow, Wendy Miller

Indiana University School of Nursing

600 Barnhill Drive

Indianapolis, IN 46202

This is the author's manuscript of the work published in final edited form as:

Tanner, A., von Gaudecker, J., Buelow, J. \& Miller, W. Hybrid concept analysis of self-management support: School nurses supporting students with psychogenic nonepileptic seizures. Journal of School Nursing. 


\begin{abstract}
Self-management support has been identified as an effective nursing intervention for improving outcomes for people with chronic conditions, yet this concept lacks a clear definition. Furthermore, the concept has not been used in school nursing literature despite the clear connection between school nursing practice and tenets of self-management support. Additionally, the concept has not been explored in the context of difficult-to-manage mental health concerns, such as psychogenic nonepileptic seizures. A conversion disorder in which seizure events in the absence of abnormal brainwave activity result from stress, psychogenic nonepileptic seizures affect the quality of life and school experience for students experiencing them and could be addressed through self-management support. This hybrid concept analysis included a review of extant literature and semi-structured interviews with school nurses to ascertain a definition of self-management support in the context of school nursing using care of students with psychogenic nonepileptic seizures as an exemplar.
\end{abstract}

Keywords: concept analysis, self-management support, psychogenic nonepileptic seizures, school nursing 


\section{Hybrid Concept Analysis of Self-Management Support: School Nurses Supporting Students with Psychogenic Nonepileptic Seizures}

The concept of self-management support (SMS) is prolific in chronic disease literature (Dineen-Griffin et al., 2019) and national healthcare initiatives (National Center for Chronic Disease Prevention and Health Promotion, 2020) but lacks consistency of definition or use. SMS broadly refers to "the help given to people with chronic conditions that enables them to manage their health on a day-to-day basis" (Agency for Healthcare Research and Quality [AHRQ], 2020, p. 1). While typically applied to adult chronic disease management, SMS is particularly relevant for the care of youth with psychogenic nonepileptic seizures (PNES) and their families, given the complexity of this mental health concern that presents as a physical health concern. More specifically, PNES appear as epileptic seizures but show no abnormal brain activity on electroencephalogram. The diagnosis, considered a stress-induced conversion disorder (Epilepsy Foundation, 2019), is frequently misunderstood by health care providers (Rawlings \& Reuber, 2018) as well as classmates and school personnel (Karterud et al., 2016).

To manage PNES day-to-day, youth with PNES and their families must navigate the medical, mental health care, and education systems. As illustrated by the National Association of School Nurses (2016) Framework for $21^{\text {st }}$ Century School Nursing Practice, the school nurse is uniquely positioned to provide SMS for students with PNES through their multidisciplinary care coordination among systems and leadership. Unfortunately, school nurses are left with a lack of knowledge and confidence related to PNES management due to scant guidance from healthcare or education systems (Tanner et al., 2020; Terry \& Trott, 2019).

Research is necessary to determine the role school nurses can and do play in supporting students with PNES. Before SMS interventions can be developed for this population, the term 
"self-management support" must be more clearly defined, especially in the context of pediatric mental health support. A concept analysis is needed to answer the research question: What is school nurse SMS, using PNES care as an exemplar?

\section{Background}

In a 10-year population-based study, the prevalence of PNES for all ages was $23.8 / 100,000$, with the highest prevalence found in the $15-19$ year age group at $59.5 / 100,000$ (Villagrán et al., 2021). Children diagnosed with PNES tend to have poorer quality of life (QOL) than their peers, especially in the domain of school functioning (Akdemir et al., 2013). With school-aged children spending $22-40 \%$ of their waking hours at school, poor school functioning can negatively impact a child's QOL. School functioning is a multifaceted concern for students with PNES, including school-related problems prior to PNES onset (Akdemir et al., 2013), schoolwork hassles, and bullying (Plioplys et al., 2014). Almost 65\% of students with PNES have irregular school attendance (Akdemir et al., 2013).

In the absence of school-specific guidance or evidence-based interventions to address school challenges for children with PNES (Tanner et al., 2020; Terry \& Trott, 2019), a review of interventions that address similar conditions may be helpful. SMS has been identified as a promising intervention for mental health conditions such as bulimia nervosa, bipolar disorder, and dementia (Carrard et al., 2006; Huis In Het Veld et al., 2018; van den Heuvel, Goossens, Terlouw, Schoonhoven, \& van Achterberg, 2018). In the pediatric population, SMS has increased self-management skills of children with diabetes (Cahill et al., 2016; Peery et al., 2012). While these studies present novel approaches to SMS, lack of a clear definition of SMS has led to a wide array of interventions that are difficult to categorize, compare, or replicate. With a clear definition of SMS, promising school nurse-led interventions that target the QOL, 
health outcomes, and academic success of students with PNES can be developed and tested.

Therefore, the purpose of this hybrid concept analysis was to develop a definition for SMS in the context of school nursing using the exemplar of providing SMS for youth with PNES.

\section{Concept Analysis Method}

We followed guidelines for conducting a hybrid concept analysis described by SchwartzBarcott and Kim (2000) as outlined in Figure 1. The hybrid model of concept analysis, which utilizes both theoretical and clinical sources to ascertain a concept definition, was selected especially for its application of theoretical concepts to specific clinical nursing circumstances (Schwartz-Barcott \& Kim, 2000) such as school nursing. To do this, the hybrid model employs three distinct phases: 1) a theoretical phase for determining a working definition of the concept based on literature, using many of the steps described by Walker and Avant (2011) to identify definitions/defining attributes, measurements, antecedents, and consequences, 2) a fieldwork phase in which qualitative data are collected from those experiencing the concept and analyzed, and 3) a final analytical phase for reexamining and refining the definition in light of fieldwork findings and relevance to school nursing (Schwartz-Barcott \& Kim, 2000).

\section{Phase 1: Theoretical Phase}

Schwartz-Barcott and Kim (2000) explain the theoretical phase as a time to "begin searching the literature, comparing and contrasting existing definitions with one's tentative definition, and moving toward the selection and creation of a working definition with which to

begin the fieldwork" (p. 131). The initial phase of the hybrid analysis included gathering relevant literature sources that addressed SMS. The search terms "self-management support AND psychogenic nonepileptic seizures," "self-management support AND child," and "selfmanagement support AND mental health" were used within CINAHL Complete, Cochrane 
Database of Systematic Reviews, MEDLINE, and PsycInfo databases. No results were found that addressed both SMS and PNES. A combined 277 results were found using the remaining search term combinations that addressed pediatric and/or mental health SMS. We assessed the titles and abstracts of articles for eligibility, with 21 articles meeting the following inclusion criteria: 1) referenced the concept of SMS or support of self-management and 2) addressed SMS within pediatric care, chronic disease care, or mental health care. No limitations were placed upon year of publication. Articles meeting inclusion criteria were published between 2009 and 2018. Selected publications were published in the United States $(n=7)$, Netherlands $(n=8)$, United Kingdom $(n=4)$, and Canada $(n=2)$ and included randomized control trials $(n=4)$, pilot/feasibility/validation trials $(n=4)$, qualitative studies $(n=4)$, reviews/reports $(n=7)$, and research protocols including SMS operational definitions $(n=2)$. Of the articles addressing chronic condition SMS, targeted populations included mostly children/young adults $(n=10)$ while a smaller portion targeted adults $(n=3)$ or all age groups $(n=2)$. For articles describing SMS for mental health conditions, targeted populations included primarily adults $(n=5)$ with only one article specifically addressing pediatric mental health SMS. Table 1 provides an overview of selected publications and study characteristics.

Once articles meeting inclusion criteria were identified, each article was evaluated for any explicit definitions of SMS. In the absence of explicit definitions, articles were reviewed for implicit definitions or attributes of SMS. Any implicit definitions of SMS, namely activities that contributed to SMS, were categorized as behavioral, educational, psychosocial, and clinical attributes (see Table 2). Measurements of SMS currently used, antecedents for SMS to occur, and consequences that result from SMS were tabulated (see Tables 1 and 2). Lastly, we developed a working definition for SMS. 


\section{Phase 2: Fieldwork Phase}

According to Schwartz-Barcott and Kim (2000), the fieldwork phase "is aimed at corroborating and refining a concept by extending and integrating the analysis begun in phase one with ongoing empirical observations" (p. 137). A small sample size of one to six individuals is recommended for this concept development model (Schwartz-Barcott \& Kim, 2000). After Indiana University-Purdue University Indianapolis' Institutional Review Board deemed the study exempt from higher review, we recruited school nurse participants who had experience caring for students with PNES via a state school nurse association email list and in-person conference. Three school nurses (all self-reported White females, all from different school districts within one Midwestern state, and with 14 to 21 years of school nursing experience) met the following inclusion criteria: 1) employed as a school nurse for at least three years and 2) cared for at least one student with PNES at school in the last year. Semi-structured interviews were conducted via Zoom video conferencing or phone, audio recorded, and transcribed by the first author.

Transcripts were broken down into meaning units and coded according to SMS definitions (explicit and implicit), measurements, antecedents, and consequences.

\section{Phase 3: Final Analytical Phase}

During the final analytical phase, Schwartz-Barcott and Kim (2000) recommend researchers answer the following questions:

1. How much is the concept applicable and important to [school] nursing?

2. Does the initial selection of the concept seem justified?

3. To what extent do the review of literature, theoretical analysis, and empirical findings support the presence and frequency of this concept within the population selected for empirical study? (p. 147) 
The analysis phase is also for "interfacing the initial theoretical analysis with insights gained from the empirical observations" (Schwartz-Barcott \& Kim, 2000, p. 132), which was completed through a side-by-side comparison of explicit and implicit definitions (including behavioral, educational, psychosocial, and clinical attributes), measurements, antecedents, and consequences of SMS identified during phases 1 and 2 (see Table 2). Using the integration of analysis findings, we revised and confirmed the definition of SMS in the context of school nursing.

\section{Results}

\section{Phase 1: Theoretical Phase}

\section{Definitions}

Almost a decade ago, Kawi (2012) undertook the task of conceptually analyzing SMS in adult chronic illness care and elicited a definition describing patient-centered, provider, and organizational attributes. The highly detailed definition encapsulates many attributes of SMS (such as patient participation, individualized and innovative education methods, provider preparation for chronic illness care, and a multidisciplinary approach using social support). Another definition comes from Haas and colleagues (2012) in their national standards for diabetes SMS: "activities that assist the person...in implementing and sustaining the behaviors needed to manage his or her condition on an ongoing basis beyond or outside of formal selfmanagement training" (p. 620). The authors continued by detailing that support could fall under the categories of "behavioral, educational, psychosocial, or clinical" (p. 620). While offering great insight into adult chronic disease SMS, these definitions fail to address some of the nuances specific to pediatric chronic health care and mental health care as well as many of the details

gleaned from more recent SMS research. Therefore, we began building upon Kawi's (2012) and Haas and colleagues' (2012) SMS definitions by integrating SMS research targeting not only 
chronic physical conditions but also mental health conditions, with a pediatric emphasis.

Articles pertaining to SMS in pediatric chronic disease care and mental health care were reviewed and uncovered a broad range of SMS definitions. Only 5 out of 21 articles included an explicit definition of SMS (Cahill et al., 2016; Henry \& Schor, 2015; Lozano \& Houtrow, 2018; McCusker et al., 2017; van Hooft et al., 2017). In van Hooft et al.’s (2017) review of SMS, a detailed definition of self-management was provided, but the topic of interest, SMS, was defined broadly as to "coach patients in their self-management"—a task that "requires a multidisciplinary approach" (p. 1256). In their pediatric report, Henry and Schor (2015) dove deeper into the details of providing SMS as "a complex but powerful process that will require the creative use of collaborative health care teams, technology, asynchronous communication, and community resources not typically relied upon" (p. 792) and emphasizing the use of "education, supportive interventions, encouragement and assistance to enhance families' skills and confidence in health promotion and the management of their children's health problems" (p. 789).

Greater than $75 \%$ of articles selected for review did not include such a clear definition. Despite the lack of a definition within 16 studies, greater understanding of SMS was gained from analyzing the implicit attributes under investigation in SMS studies. These implicit definitions or attributes of SMS were categorized according to Haas and colleagues' (2012) support categories of "behavioral, educational, psychosocial, or clinical" (p. 620) and are detailed in Table 2. Behavioral attributes of SMS included various forms of goal setting, communicating responsibilities of people involved in SMS, writing action plans, monitoring progress, and coaching. Educational attributes involved providing information or resources in spoken and written forms. The psychosocial aspects of SMS encompassed emotion and identity management training, exploring societal roles while managing the condition, and facilitating support from 
peers, health care providers, family, and pets/animals. The clinical focus of SMS integrated condition-specific medical regimen adherence into the whole-person focus of SMS activities. See Table 2 for examples and references for each category.

\section{Measurements}

When authors fail to provide a definition of a concept, they may reveal an implicit definition through the use of an instrument that measures the concept's key attributes (SchwartzBarcott \& Kim, 2000). McCusker and colleagues (2017) developed and validated patient-report measures of SMS from health care professionals for mood and emotional problems. The measures that were examined align with the aforementioned realms: behavioral ("staying healthy", "improving health", how to "do treatments", and "discussion of personal goals and how to reach them"), educational ("helpfulness of information received on adhering to treatment", "explanations about impact of the health condition"), psychosocial ("coping with minor complications"), and clinical (why to "do treatments", "required monitoring", and "visits with other health professionals") (McCusker et al., 2017, p. 2313).

\section{Antecedents}

Antecedents are events or situations that must occur before the stated concept can occur and provide social context for a concept (Walker \& Avant, 2011). For all selected works, an assumed antecedent of SMS was the existence of a condition that needed "management" by someone. Additional obvious but critical antecedents include patients attending a clinic/setting where the opportunity for SMS is offered (Been-Dahmen et al., 2015), returning to a clinic for routine care that may coincide with SMS (Van Bragt et al., 2015), receiving technology tools and appropriate training on how to use them (Hommel et al., 2015), and reading at a level that matches written materials (Milton et al., 2017; Sharpe et al., 2017). Also, there should be some 
need for knowledge, behavior change, coping, motivation, or self-efficacy (van Hooft et al., 2017) or a need for transition from parent control of care to child control of care (Marjolijn et al., 2016). In the instance of pediatric SMS, being the caregiver of someone with a chronic or mental health condition is an antecedent (Cahill et al., 2016; Morrison et al., 2014).

In addition to these somewhat obvious and often assumed antecedents, several other antecedents speak to the readiness of the patient to receive SMS. Krieger and colleagues (2009) and Milton and colleagues (2017) identified having a connection with the coach/trainer/provider as a key to SMS success. In more high-tech SMS, this friendship or connection may be with a robot and/or avatar (Sinoo et al., 2018). Additionally, successful SMS should start with a patient having at least moderate self-efficacy perception (belief that goals can be met) (Shomaker \& DeVeau-Rosen, 2016), intrinsic capacity, performance ability (Lozano \& Houtrow, 2018), and internal motivation to do the work of such therapy as cognitive behavioral therapy (CBT; Hensel et al., 2016). Being committed to a sometimes lengthy program may also be a prerequisite for SMS (Milton et al., 2017), although partial exposure could still constitute SMS and lead to desired outcomes.

Patients and caregivers are not the only ones with pre-qualifications for SMS; providers also must maintain certain knowledge, skills, and attitudes to make SMS successful. To begin, health care providers need to be able to recognize a health concern that would benefit from SMS (Ludman et al., 2016; McCusker et al., 2017). This includes health care providers understanding a child's dependency on parents and the developmental stage of the child, which may impact readiness for his or her active role in SMS (Lozano \& Houtrow, 2018). Furthermore, providers of SMS need to be competent and confident in their ability to provide SMS (McCusker et al., 2017), especially understanding patients' preferences for SMS content and structure (Ammerlaan 
et al., 2017). Allowing SMS to be patient-centered requires the provider to be able to relinquish some control as well as balance ethical dilemmas that arise when patient autonomy could result in poorer health outcomes (Dwarswaard \& van de Bovenkamp, 2015).

\section{Consequences}

Henry and Schor (2015) eloquently summarized the overarching consequences, or outcomes, of SMS: "Activate and engage patients to support the acquisition of the knowledge, skills, and confidence requisite to their involvement in managing their health and care" (p. 790). More specifically, SMS consequences included decrease in symptom-free days (Krieger et al., 2009), improved care giver and patient QOL (Krieger et al., 2009; Morrison et al., 2014; Sattoe et al., 2015; Van Bragt et al., 2015), appropriate use of medication and treatment adherence (Krieger et al., 2009; Marjolijn et al., 2016; Morrison et al., 2014), disease and treatment knowledge (Marjolijn et al., 2016; Sattoe et al., 2015), decrease in depressive symptoms, and patient perception of recovery (Ludman et al., 2016).

\section{Working definition}

Integrating adult chronic disease SMS definitions, including AHRQ’s broad definition, with theoretical phase findings from this analysis of adult and pediatric definitions and attributes resulted in the following working SMS definition:

Self-management support is a comprehensive approach to improving health and QOL outcomes for youth with conditions requiring day-to-day management. SMS includes a child/family-centered approach; a provider knowledgeable and skilled in chronic condition care, plan development, and coaching; and a collaboration between the child, family, and health care team to address the student and family' behavioral, educational, psychosocial, and clinical needs for day-to-day condition management. 


\section{Phase 2: Fieldwork Phase}

\section{Definitions}

Many definitions of SMS were derived from semi-structured interviews with school nurses.

Definitions of SMS by school nurses included:

- 'How to empower the student without discounting the parent's concerns for her soon-tobe unsupervised student."

- "Assistance to any student experiencing a health issue which becomes evident in their lives to the detriment of participating fully in life at school, (i.e. participation in class or socialization, field trips, extra-curricular activities) to not only improve their health and ability to participate more fully in school, but instill the confidence in the student to recognize signs and symptoms of their health issue and address them personally or with the assistance of others in a timely manner to lessen the negative impact their health issue has on their life."

- "It means to help the student get to the optimal place where he can learn, feel safe, and be able to participate in his education plan."

- "Teach kids about how to manage their problems, to head things off, before they get urgent, recognize the signs and symptoms of a problem early so they can intervene, becoming more self-sufficient."

The explicit definitions provided by these school nurses were supported with implied behavioral, educational, psychosocial, and clinical attributes of SMS described during the interviews. Consequently, all tasks and attributes that school nurses considered to be part of SMS were categorized into one of these four categories.

Behavioral. School nurses reported doing various tasks or assuming roles that constitute 
SMS. Plan development was mentioned by all three school nurses and included such activities as exploring options, ascribing a Likert-type scale for students to communicate anxiety or stress level, and setting boundaries. One nurse explained that her student's plan included, "Stop, deep breathe, find what the triggers were and what can help de-escalate what was going on either with himself, mentally, or the stressors inside the classroom". Another school nurse described her role in developing a Section 504 plan or modifying an individualized education plan (IEP) to allow "time out"- exiting class to come to the clinic at onset of anxiety symptoms to listen to music, use a calming smartphone application, or call a mental health caseworker to talk. Allowing extra time to complete school assignments to decrease stress or to compensate for time spent in the health office or seeking mental health care outside of school was another accommodation mentioned. Nurses described these plans and accommodations being developed with both the student and the parent's involvement, and often also involved teachers or other school personnel.

In addition to developing a plan of care, two of the three school nurses likened their role to a coach. They described coaching students to talk to their teachers when they felt in crisis or to implement a pre-determined plan if they felt an impending event. They also coached students on making health choices, such as getting enough sleep and keeping mental health care appointments. One school nurse also mentioned "walking through the situation" with the student to discover what parts of their plan worked and what could be done differently in the future.

A key task in plan development and coaching students was communication. School nurses reported communicating with their students about the health care action plan developed with their health care providers and about "triggers leading to full-blown anxiety attack that turn into PNES". One school nurse mentioned talking with her student about "what happened", the "why", and what worked to de-escalate himself. In addition to communicating with students, 
school nurses identified communication with parents or guardians as an SMS activity. Two of the three interviewed school nurses mentioned making follow-up phone calls to a parent or guardian to report how a student's self-management activities were impacting their PNES experience. Yet another key communication activity included the school nurse debriefing with the student, staff, and parent/guardian after a PNES event to discuss any strategies that helped improve the situation or were not effective before, during, or after the event.

Educational. School nurses reported several educationally focused activities, including assessing both student and parent knowledge of the condition, sharing information, providing tools, and using a written plan from the diagnosing health care provider to provide one-on-one education with the student about PNES. Two of the three school nurses discussed the importance of sharing information about the PNES diagnosis with teachers and school personnel.

Psychosocial. Because PNES is a mental health condition, several themes arose related to the psychosocial nature of the condition. One school nurse declared the importance of her SMS role in helping students with PNES increase their confidence in self-advocacy and balancing parent concern with the students' desire for "freedom". Another school nurse SMS task involved building a relationship with the parents/guardians to foster trust in the school nurse and in the students' ability to self-manage their condition.

Other psychosocially oriented tasks were more specific, including providing students with alternative "safe places" or "outs" when they felt a PNES event might occur, offering a calm environment with dimmed lights and calm music, talking with the student to keep anxiety from escalating, and allowing the student with increasing anxiety to assist another student as a distraction tactic. One school nurse described her SMS activity as "helping the student be able to do the steps in his own head... before it gets to the point where the anxiety is too much that he 
shuts down and the only thing he can do to handle the stress is to have a PNES because he is no longer in control of the situation." All school nurses agreed that their role was not just focusing on the physical aspects of the seizure event, but on the anxiety or stress that triggered the PNES.

Clinical. The clinical attributes of SMS received less attention from school nurses than the other attributes. However, school nurses did discuss their concerns regarding the long-term effects of not seeking appropriate care, keeping mental health care appointments, and acquiring medications to treat co-morbid conditions. One school nurse also stated that she spoke with a student's other healthcare providers about tools to help the student.

\section{Measurements}

School nurses were not aware of any tools that measured SMS. However, they were able to identify several variables they felt exemplified key indicators of successful SMS, including student's willingness to participate in SMS activities, confidence in self-managing the condition, and participation in mental health care. Measures that could be completed by a parent/guardian, teacher, or school nurse included level of student involvement in advocating for self (to prevent a trigger from leading to a PNES event) and teacher understanding of the condition.

\section{Antecedents}

When asked what needed to be in place before school nurses could provide SMS, answers were varied. Some responses reflected a means of knowing SMS was needed, including evidence of poor self-management in the past or poor school attendance due to PNES. Other responses reflected a state of student or family readiness to receive SMS, such as being willing to participate, being motivated to change, or having mutual respect between student and nurse or parent and nurse. Other antecedents involved the student being under the care of a mental health care provider to confirm diagnosis, prescribe medication for co-morbid condition as appropriate, 
and provide a health care action plan to inform the school nurse's care at school. The school nurse having confidence in presenting material about the condition and expecting positive outcomes in students' self-management capabilities were also noted as antecedents.

\section{Consequences}

The school nurses interviewed witnessed numerous positive consequences believed to be a result of their SMS efforts. These included: fewer and/or less severe exacerbations of illness, better attendance in school, better academic outcomes, better social relationships, more participation in life activities, happier disposition, improved confidence, improved selfadvocacy, and reduction in fear of being "different" or "out of control". Students used tools gained through SMS to control the anxiety response to stress resulting in fewer visits to the health office. For a student misdiagnosed with epilepsy, once the correct diagnosis of PNES was delivered and a health care action plan appropriate for PNES was provided to the school nurse, a decrease in number of seizures was noted. School nurses also cited observing students express understanding of their condition, greater confidence taking protective action when feeling a PNES event approaching, and greater sense of control over their education and stressors.

\section{Working definition reflections}

While Phase 3 involves interfacing the working definition of Phase 1 with Phase 2 findings, it is important to reflect upon the contributions school nurses' experiences with SMS for students with PNES have upon understanding SMS as a concept and intervention. School nurse SMS is unique based upon the setting, age and developmental stage of students receiving the support, needs of students in and out of the school setting, skills and knowledge of school nurses, and students' reliance upon family and school personnel for some aspects of their health and safety. These distinctive characteristics of SMS provided by school nurses are not reflected 
in the working definition of SMS from Phase 1. Phase 3 interfaces these school nurse-specific SMS attributes identified during Phase 2 with the working definition from Phase 1 for a school nurse-informed SMS definition.

\section{Phase 3: Final Analytical Phase}

In response to the guiding questions posed by Schwartz-Barcott and Kim (2000), it is evident that SMS is both applicable and important for school nurses caring for students with PNES. The selection of SMS as a concept is extremely relevant, especially considering that there are no evidence-supported published findings in school nurse, medical, or psychological journals to guide school nurses in the care they provide students with PNES. Furthermore, school nurses report struggling to identify appropriate interventions to support students with PNES, both in these interviews and in existing literature (Terry \& Trott, 2019). The theoretical analysis and empirical findings suggest much more emphasis should be placed on supporting students with PNES in school, and school nurses providing SMS is a practical solution for addressing the greatest concerns of children with PNES- school relationships, attendance, and performance.

\section{Interfacing Phase 1 and Phase 2 Definitions}

When comparing SMS definitions found in literature and provided by school nurses, similarity was found between school nurses' definition and Cahill and colleagues' (2016) definition focusing on the transition between parent management and student management. Van Hooft and colleagues (2017) offered a definition like that of school nurses that addressed coaching the patient in self-management skills. Henry and Schor (2015) reflected school nurses' experience in their emphasis on the family's role in health promotion and the family's need for confidence in providing care; however, Henry and Schor (2015) failed to recognize the combined role of family and child together managing a health condition. Analyzing behavioral, 
educational, psychosocial, and clinical attribute categories of SMS highlights further variability in implied conceptual definitions, or attributes, between literature and reality for school nurses.

Behavioral. The importance of goal setting and having a written plan was an integral part of SMS in both literature and in the field. The role of coaching was also a key element, although the person in the role of coach within the literature was a community health worker, mental health care specialist, or peer with similar condition or ethnic background; in the field, the school nurse was the person considered to be the coach. School nurses had not considered involving any other person to coach students with PNES; rather, they used their own relationship with the student to build a coaching relationship. Communication through follow up calls or "check-ins" was a theme through both literature and school nurse interviews.

Educational. The patient-centered approach recommended by Shomaker and DeVeauRosen (2016) and the individual-paced approach of Ammerlaan and colleagues (2017) compliment the school nurses' one-on-one education approach for students with PNES. One very distinct difference is that no authors, even those conducting pediatric SMS research, reported providing any education for teachers. While school nurses emphasized the importance of educating teachers, this serious oversight by other pediatric researchers is concerning when school-aged children likely spend more time with their teacher(s) than their parents during the school year. School nurses consistently mentioned the importance of educating teachers regarding their students' health conditions.

Psychosocial. Within the theoretical phase, relationships were a fundamental theme. Henry and Schor (2015) emphasized the importance of the relationship between the child, parent, and health care provider while Lozano and Houtrow (2018) discussed the parent-child relationship in the context of "shared management." Similarly, in the fieldwork phase, school 
nurses identified critical relationships in the SMS process but included themselves in this relationship unit as well as the student's teacher. One untapped social strategy for school nurses may be utilizing peer support, which was strongly supported in literature (Henry \& Schor, 2015; Hensel et al., 2016; Marjolijn et al., 2016), but was only mentioned once by school nurses in the context of a student with PNES helping brighten the day of a student with a different condition.

Within trusting relationships with health care providers or peers, students can learn valuable psychological skills. In the literature, Marjolijn and colleagues (2016) mentioned cognitive restructuring as a SMS activity. On the other hand, school nurses focused on teaching coping strategies and coaching students with PNES in the use of these strategies, especially in the context of anxiety and stress responses. Interestingly, while researchers have identified bullying as a concern for students with PNES (Morgan \& Buchhalter, 2015), none of the school nurses in the field mentioned bullying as a concern.

Clinical. Much of the rhetoric from the theoretical and fieldwork phases that addressed clinical attributes was analogous. One noticeable difference is that school nurses did not explicitly discuss incorporating day-to-day life topics, a recommendation for SMS within the literature (Been-Dahmen et al., 2015; Brooks et al., 2016; Henry \& Schor, 2015). One explanation is that school nurses are performing SMS outside of the health care setting, making their interactions naturally more "day-to-day" focused than SMS that may occur in the health care setting. One additional distinction noted between the phases is that school nurses often mentioned communicating directly with health care providers as a part of SMS, yet there was no mention of this approach in any pediatric oriented literature. In addition, there was no evidence or recommendations in extant literature for health care providers to collaborate with school nurses to ensure continuity of care outside the health care setting. 


\section{School Nurse-Informed Working Definition}

Taking into consideration information gained from school nurses in the fieldwork phase, the SMS working definition was adapted to reflect the school nurse's role in SMS for students:

School nurse self-management support is a comprehensive approach to improving health, academic, and QOL outcomes for students with conditions requiring day-to-day management. School nurse SMS includes a student/family-centered approach; a school nurse knowledgeable and skilled in whole-child care, individualized health plan development, and coaching; and a collaboration between the student, family, school, and health care team to address the behavioral, educational, psychosocial, and clinical needs of the student and everyone responsible for day-to-day shared condition management.

With this well-informed definition, further research can be conducted, and SMS for PNES can be tested and rigorously evaluated for effectiveness.

\section{Discussion}

\section{Implications for School Nursing Practice}

While examined studies presented innovative approaches to SMS beyond the broad definition offered by AHRQ (2020), lack of a school nurse-informed SMS definition could lead to school nurse activities that inadequately address the needs of students with PNES. With a clear definition of SMS, school nurse interventions targeting the QOL, health, and academic needs of students with PNES can be formalized and tested.

Specific strategies used by school nurses to help students self-manage PNES and improve QOL, mental health, and academic outcomes of these students are listed in Table 2. Many strategies listed are synonymous with those listed in the Framework for $21^{\text {st }}$ Century School Nursing Practice key principle of care coordination (National Association of School Nurses, 
2016). These strategies have not been rigorously tested for effectiveness but could inform PNES care planning until higher quality evidence is available. Differences between theoretical and fieldwork findings in this analysis highlight the importance of school nurses providing education about PNES to teachers of students with PNES, as teacher perception of students' psychosocial functioning may impact students' QOL (Akdemir et al., 2013). Missing from the psychosocial strategies of school nurses, but supported in research, was assessing the potential role of bullying, both as a trigger for and result of PNES, and utilizing evidence-supported motivational interviewing and CBT interventions (Bonde et al., 2014; Drake et al., 2015; Haugland et al., 2020).

With rising health care costs and a need for more outpatient mental health care options (Kaiser Family Foundation, 2020), considering the role school nurses can play in supporting mental health wellbeing is a practical idea. School nurses provide direct care, routine follow-up, home visits, and mental health support with no added cost to families, the health care system, or society. These tasks are already a part of the role of the school nurse (NASN, 2016) and address health inequities related to socioeconomic barriers (National Academy of Medicine, 2021). Furthermore, future SMS interventions can target what matters most to students in the school setting where they spend a large portion of their childhood years.

\section{Limitations and Recommendations}

Several limitations surrounding this conceptual analysis exist. First, the analysis included a limited literature search that may have inadvertently excluded key articles on the topic of SMS or related concepts. However, using the hybrid analysis approach helped mitigate negative effects of any oversight by incorporating the voices of school nurses with experience in SMS. Second, not all students have access to a school nurse who can deliver SMS; $25 \%$ of schools do 
not employ a school nurse and only $39 \%$ of schools employ a school nurse full time (Willgerodt et al., 2018). Findings of this analysis are limited to understanding SMS for students who have routine access to a school nurse. Finally, the fieldwork phase focused primarily on school nurses' experience with SMS for students with PNES. The current definition from this hybrid concept analysis should be explored in additional fieldwork with a broader population of school nurses and health conditions before being used universally for school nurse SMS. Additionally, further fieldwork should be conducted by interviewing students with PNES or other conditions and their families to capture their perceived SMS needs and preferences.

\section{Conclusion}

Despite school nurses being uniquely positioned to address the unmet health needs of students with PNES, there is no research or guidelines for the role school nurses play in caring for students with PNES. SMS is a promising approach for school nurses interested in improving outcomes for students with PNES, but current literature lacks a definition of SMS applicable to school nurses. The definition of SMS provided in this concept analysis can inform future research on the provision of SMS for children with PNES by school nurses. Much research is needed regarding potential SMS interventions, school nurses' role in providing SMS, and student outcomes amenable to SMS. While SMS has potential to improve self-management and outcomes for students with PNES, no evidence supports this hypothesis. Research that focuses on the effectiveness of behavioral, educational, psychosocial, and clinical attributes of SMS is urgently needed. Research will generate the necessary evidence to develop SMS interventions and examine their effects on QOL, health, and academic outcomes of students managing PNES. 


\section{References}

Agency for Healthcare Research and Quality. (2020). Self-Management Support. https://www.ahrq.gov/ncepcr/tools/self-mgmt/self.html

Akdemir, D., Uzun, Ö., Pehlivantürk Özsungur, B., Topçu, M., Özsungur, B. P., \& Topçu, M. (2013). Health-related quality of life in adolescents with psychogenic nonepileptic seizures. Epilepsy \& Behavior, 29(3), 516-520. https://doi.org/10.1016/j.yebeh.2013.09.015

Ammerlaan, J. W., van Os-Medendorp, H., de Boer-Nijhof, N., Maat, B., Scholtus, L., Kruize, A. A., Bijlsma, J. W., \& Geenen, R. (2017). Preferences and needs of patients with a rheumatic disease regarding the structure and content of online self-management support. Patient Education \& Counseling, 100(3), 501-508.

https://doi.org/https://dx.doi.org/10.1016/j.pec.2016.10.009

Been-Dahmen, J. M. J., Dwarswaard, J., Hazes, J. M. W., van Staa, A., \& Ista, E. (2015). Nurses' views on patient self-management: A qualitative study. Journal of Advanced Nursing, 71(12), 2834-2845. https://doi.org/10.1111/jan.12767

Bonde, A. H., Bentsen, P., \& Hindhede, A. L. (2014). School nurses' experiences with motivational interviewing for preventing childhood obesity. Journal of School Nursing, 30(6), 448-455. https://doi.org/10.1177/1059840514521240

Brooks, H., Rushton, K., Walker, S., Lovell, K., \& Rogers, A. (2016). Ontological security and connectivity provided by pets: A study in the self-management of the everyday lives of people diagnosed with a long-term mental health condition. BMC Psychiatry, 16(1), 1-12. https://doi.org/10.1186/s12888-016-1111-3

Cahill, S. M., Polo, K. M., Egan, B. E., Marasti, N., \& Cahill, S. M., Polo, K. M., Egan, B. E., M. N. (2016). Interventions to promote diabetes self-management in children and youth: A 
scoping review. The American Journal of Occupational Therapy, 70(5), 7005180020p1-8. https://doi.org/10.5014/ajot.2016.021618

Carrard, I., Rouget, P., Fernández-Aranda, F., Volkart, A.-C., Damoiseau, M., \& Lam, T. (2006). Evaluation and deployment of evidence based patient self-management support program for bulimia nervosa. International Journal of Medical Informatics, 75(1), 101-109. https://doi.org/10.1016/J.IJMEDINF.2005.07.031

Dineen-Griffin, S., Garcia-Cardenas, V., Williams, K., \& Benrimoj, S. I. (2019). Helping patients help themselves: A systematic review of self-management support strategies in primary health care practice. PLoS ONE, 14(8), 1-29.

https://doi.org/10.1371/journal.pone.0220116

Drake, K. L., Stewart, C. E., Muggeo, M. A., \& Ginsburg, G. S. (2015). Enhancing the capacity of school nurses to reduce excessive anxiety in children: Development of the CALM intervention. Journal of Child and Adolescent Psychiatric Nursing, 28(3), 121-130. https://doi.org/10.1111/jcap.12115

Dwarswaard, J., \& van de Bovenkamp, H. (2015). Self-management support: A qualitative study of ethical dilemmas experienced by nurses. Patient Education and Counseling, 98(9), 11311136. https://doi.org/10.1016/j.pec.2015.05.017

Epilepsy Foundation. (2019). The Truth about Psychogenic Nonepileptic Seizures. https://www.epilepsy.com/article/2014/3/truth-about-psychogenic-nonepileptic-seizures

Haas, L., Maryniuk, M., Beck, J., Cox, C. E., Duker, P., Edwards, L., Fisher, E. B., Hanson, L., Kent, D., Kolb, L., McLaughlin, S., Orzeck, E., Piette, J. D., Rhinehart, A. S., Rothman, R., Sklaroff, S., Tomky, D., Youssef, G., \& 2012 Standards Revision Task Force, on behalf of the 2012 S. R. T. (2012). National standards for diabetes self-management education and 
support. Diabetes Care.

http://journals.sagepub.com.proxy.ulib.uits.iu.edu/doi/pdf/10.1177/0145721712455997

Haugland, B. S. M., Haaland, Å. T., Baste, V., Bjaastad, J. F., Hoffart, A., Rapee, R. M., Raknes, S., Himle, J. A., Husabø, E., \& Wergeland, G. J. (2020). Effectiveness of Brief and Standard School-Based Cognitive-Behavioral Interventions for Adolescents With Anxiety: A Randomized Noninferiority Study. Journal of the American Academy of Child and Adolescent Psychiatry, 59(4), 552-564.e2. https://doi.org/10.1016/j.jaac.2019.12.003

Henry, H. K. M., \& Schor, E. L. (2015). Supporting self-management of chronic health problems. Pediatrics, 135(5), 789-792. https://doi.org/10.1542/peds.2014-3431

Hensel, J. M., Shaw, J., Jeffs, L., Ivers, N. M., Desveaux, L., Cohen, A., Agarwal, P., Wodchis, W. P., Tepper, J., Larsen, D., McGahan, A., Cram, P., Mukerji, G., Mamdani, M., Yang, R., Wong, I., Onabajo, N., Jamieson, T., \& Bhatia, R. S. (2016). A pragmatic randomized control trial and realist evaluation on the implementation and effectiveness of an internet application to support self-management among individuals seeking specialized mental health care: A study protocol. BMC Psychiatry, 16(1), 1-11. https://doi.org/10.1186/s12888-016-1057-5

Hommel, K. A., Gray, W. N., Hente, E., Loreaux, K., Ittenbach, R. F., Maddux, M., Baldassano, R., Sylvester, F., Crandall, W., Doarn, C., Heyman, M. B., Keljo, D., \& Denson, L. A. (2015). The Telehealth Enhancement of Adherence to Medication in Pediatric IBD (TEAM) Trial: Design and methodology. Contemporary Clinical Trials, 43, 105-113. https://doi.org/10.1016/j.cct.2015.05.013

Huis In Het Veld, J. G., Verkaik, R., van Meijel, B., Verkade, P.-J., Werkman, W., Hertogh, C. M. P. M., \& Francke, A. L. (2018). Self-management support and eHealth when managing 
changes in behavior and mood of a relative with dementia: An asynchronous online focus group study of family caregivers' needs. Research in Gerontological Nursing, 11(3), 151159. https://doi.org/10.3928/19404921-20180216-01

Kaiser Family Foundation. (2020). Mental health care health professional shortage areas (HPSAs). https://www.kff.org/other/state-indicator/mental-health-care-health-professionalshortage-areashpsas/?currentTimeframe $=0 \&$ sortModel $=\% 7 \mathrm{~B} \% 22$ colId $\% 22: \% 22$ Location $\% 22, \% 22$ sort $\% 2$ $2: \% 22 \operatorname{asc} \% 22 \% 7 \mathrm{D}$

Karterud, H. N., Haavet, O. R., \& Risor, M. B. (2016). Social participation in young people with nonepileptic seizures (NES): A qualitative study of managing legitimacy in everyday life. Epilepsy \& Behavior, 57, 23-28. https://doi.org/10.1016/j.yebeh.2016.01.009

Kawi, J. (2012). Self-management support in chronic illness care: A Concept analysis. Research and Theory for Nursing Practice: An International Journal, 26(2), 108-126. https://doi.org/http://dx.doi.org/10.1891/1541-6577.26.2.108

Krieger, J., Takaro, T. K., Song, L., Beaudet, N., \& Edwards, K. (2009). A randomized controlled trial of asthma self-management support comparing clinic-based nurses and inhome community health workers. Archives of Pediatrics \& Adolescent Medicine, 163(2), 141. https://doi.org/10.1001/archpediatrics.2008.532

Lozano, P., \& Houtrow, A. (2018). Supporting self-management in children and adolescents with complex chronic conditions. Pediatrics, 141(Supplement 3), S233-S241. https://doi.org/http://dx.doi.org/10.1542/peds.2017-1284H

Ludman, E. J., Simon, G. E., Grothaus, L. C., Richards, J. E., Whiteside, U., \& Stewart, C. (2016). Organized self-management support services for chronic depressive symptoms: A 
randomized controlled trial. Psychiatric Services, 67(1), 29-36.

https://doi.org/10.1176/appi.ps.201400295

Marjolijn, I. B., Sattoe, J. N. T., Roelofs, P. D. D. M., Bal, R., van Staa, A., \& Miedema, H. S. (2016). Exploring effectiveness and effective components of self-management interventions for young people with chronic physical conditions: A systematic review. Patient Education and Counseling, 99(8), 1293-1309. https://doi.org/10.1016/j.pec.2016.02.012

McCusker, J., Haggerty, J., De Raad, M., Belzile, E., Bouharaoui, F., Beaulieu, C., Yaffe, M., \& Ciampi, A. (2017). Development and validation of subscales to assess perceived support for self-management of mood or emotional problems: Results from a randomized trial. Patient Education and Counseling, 100(12), 2312-2319. https://doi.org/10.1016/j.pec.2017.06.002

Milton, A., Lloyd-Evans, B., Fullarton, K., Morant, N., Paterson, B., Hindle, D., Kelly, K., Mason, O., Lambert, M., \& Johnson, S. (2017). Development of a peer-supported, selfmanagement intervention for people following mental health crisis ISRCTN01027104 ISRCTN. BMC Research Notes, 10(1), 1-18. https://doi.org/10.1186/s13104-017-2900-6

Morgan, L. A., \& Buchhalter, J. (2015). Psychogenic paroxysmal nonepileptic events in children: A review. Pediatric Neurology, 53(1), 13-22. https://doi.org/10.1016/j.pediatrneurol.2015.03.017

Morrison, D., Wyke, S., Agur, K., Cameron, E. J., Docking, R. I., MacKenzie, A. M., McConnachie, A., Raghuvir, V., Thomson, N. C., \& Mair, F. S. (2014). Digital asthma selfmanagement interventions: A systematic review. Journal of Medical Internet Research, 16(2). https://doi.org/10.2196/jmir.2814

National Academy of Medicine. (2021). The future of nursing 2020-2030: Charting a path to achieve health equity. In The Future of Nursing 2020-2030. The National Academies Press. 
https://doi.org/10.17226/25982

National Association of School Nurses. (2016). Framework for 21st Century School Nursing Practice. https://www.nasn.org/nasn/nasn-resources/professional-topics/framework

National Center for Chronic Disease Prevention and Health Promotion. (2020). Self-management support and education. In Best Practices for Cardiovascular Disease Prevention Programs.

Peery, A. I., Engelke, M. K., \& Swanson, M. S. (2012). Parent and teacher perceptions of the impact of school nurse interventions on children's self-management of diabetes. The Journal of School Nursing, 28(4), 268-274. https://doi.org/10.1177/1059840511433860

Plioplys, S., Doss, J., Siddarth, P., Bursch, B., Falcone, T., Forgey, M., Hinman, K., LaFrance, W. C., Laptook, R., Shaw, R. J., Weisbrot, D. M., Willis, M. D., \& Caplan, R. (2014). A multisite controlled study of risk factors in pediatric psychogenic nonepileptic seizures. Epilepsia, 55(11), 1739-1747. https://doi.org/10.1111/epi.12773

Rawlings, G. H., \& Reuber, M. (2018). Health care practitioners' perceptions of psychogenic nonepileptic seizures: A systematic review of qualitative and quantitative studies. Epilepsia, 59(6), 1109-1123. https://doi.org/10.1111/epi.14189

Sattoe, J. N. T., Bal, M. I., Roelofs, P. D. D. M., Bal, R., Miedema, H. S., \& van Staa, A. (2015). Self-management interventions for young people with chronic conditions: A systematic overview. Patient Education and Counseling, 98(6), 704-715. https://doi.org/10.1016/j.pec.2015.03.004

Schwartz-Barcott, D., \& Kim, H. S. (2000). An expansion and elaboration of the hybrid model of concept development. In B. L. Rodgers \& K. A. Knafl (Eds.), Concept development in Nursing: Foundations, techniques, and applications (2nd ed., pp. 161-192). Saunders. Sharpe, H., Patalay, P., Vostanis, P., Belsky, J., Humphrey, N., \& Wolpert, M. (2017). Use, 
acceptability and impact of booklets designed to support mental health self-management and help seeking in schools: Results of a large randomised controlled trial in England. European Child and Adolescent Psychiatry, 26(3), 315-324.

https://doi.org/10.1007/s00787-016-0889-3

Shomaker, K. L., \& DeVeau-Rosen, S. H. (2016). Feasibility of a worksheet for facilitating selfmanagement in children with asthma. Journal of Asthma, 53(4), 419-426. https://doi.org/10.3109/02770903.2015.1101472

Sinoo, C., van der Pal, S., Blanson Henkemans, O. A., Keizer, A., Bierman, B. P. B., Looije, R., \& Neerincx, M. A. (2018). Friendship with a robot: Children's perception of similarity between a robot's physical and virtual embodiment that supports diabetes self-management. Patient Education and Counseling, 101(7), 1248-1255.

https://doi.org/10.1016/j.pec.2018.02.008

Tanner, A., Miller, W. R., Von Gaudecker, J., \& Buelow, J. M. (2020). An integrative review of school-based mental health interventions and implications for psychogenic nonepileptic seizures. Journal of School Nursing, 36(1), 33-48.

https://doi.org/10.1177/1059840519854796

Terry, D., \& Trott, K. (2019). A qualitative analysis of school nurses' experience caring for students with psychogenic nonepileptic events. Journal of School Nursing, 1-8. https://doi.org/https://doi.org/10.1177\%2F1059840519889395

Van Bragt, S., Van Den Bemt, L., Kievits, R., Merkus, P., Van Weel, C., \& Schermer, T. (2015). PELICAN: A cluster-randomized controlled trial in Dutch general practices to assess a selfmanagement support intervention based on individual goals for children with asthma. Journal of Asthma, 52(2), 211-219. https://doi.org/10.3109/02770903.2014.952439 
van den Heuvel, S., Goossens, P., Terlouw, C., Schoonhoven, L., \& van Achterberg, T. (2018). Informal caregivers' learning experiences with self-management support of individuals living with bipolar disorder: A phenomenological study. Journal of the American Psychiatric Nurses Association, 00(0), 1-11. https://doi.org/10.1177/1078390317752864

van Hooft, S. M., Been-Dahmen, J. M. J., Ista, E., van Staa, A. L., \& Boeije, H. R. (2017). A realist review: what do nurse-led self-management interventions achieve for outpatients with a chronic condition? Journal of Advanced Nursing, 73(6), 1255-1271. https://doi.org/10.1111/jan.13189

Villagrán, A., Eldøen, G., Duncan, R., Aaberg, K. M., Hofoss, D., \& Lossius, M. I. (2021). Incidence and prevalence of psychogenic nonepileptic seizures in a Norwegian county: A 10-year population-based study. Epilepsia, 62, 1528-1535. https://doi.org/10.1111/epi.16949

Walker, L., \& Avant, K. (2011). Strategies for theory construction in nursing (5th ed.). Prentice Hall.

Willgerodt, M. A., Brock, D. M., \& Maughan, E. D. (2018). Public school nursing practice in the United States. Journal of School Nursing, 34(3), 232-244. https://doi.org/10.1177/1059840517752456

Yadav, A., Agarwal, R., \& Park, J. (2015). Outcome of psychogenic nonepileptic seizures (PNES) in children: A 2-year follow-up study. Epilepsy \& Behavior, 53, 168-173. doi: https://doi.org/10.1016/j.yebeh.2015.10.017 


\section{Table 1}

Self-management support literature review articles and key details

\begin{tabular}{|c|c|c|c|c|c|c|c|c|c|}
\hline $\begin{array}{l}\text { First } \\
\text { Author, } \\
\text { Year }\end{array}$ & Country & Design & $\begin{array}{l}\text { Discipline/ } \\
\text { Setting }\end{array}$ & SMS Delivery & Population & Theory & $\begin{array}{l}\text { Antecedents of } \\
\text { SMS }\end{array}$ & Attributes of SMS & $\begin{array}{l}\text { Consequences } \\
\text { of SMS }\end{array}$ \\
\hline \multicolumn{10}{|c|}{ SMS for Chronic Conditions } \\
\hline $\begin{array}{c}\text { Ammer- } \\
\text { laan, } 2017\end{array}$ & $\begin{array}{l}\text { Nether- } \\
\text { lands }\end{array}$ & Qualitative & $\mathrm{N} / \mathrm{A}$ & $\begin{array}{l}\text { N/A. Study } \\
\text { discussed that } \\
\text { some preferred } \\
\text { receiving SMS } \\
\text { from patient } \\
\text { expert rather } \\
\text { than health } \\
\text { care provider } \\
\text { expert. }\end{array}$ & $\begin{array}{l}\text { Adults with } \\
\text { rheumatic } \\
\text { diseases }\end{array}$ & $\begin{array}{l}\text { Self- } \\
\text { determi- } \\
\text { nation } \\
\text { theory, } \\
\text { self- } \\
\text { efficacy } \\
\text { theory }\end{array}$ & $\begin{array}{l}\text { Provider } \\
\text { understanding } \\
\text { of patients' } \\
\text { preferences for } \\
\text { content and } \\
\text { structure. }\end{array}$ & $\begin{array}{l}\text { Individual needs, } \\
\text { stage of life/disease } \\
\text { process; individual } \\
\text { paced; address } \\
\text { knowledge, physical } \\
\text { activity, } \\
\text { psychological } \\
\text { distress, self- } \\
\text { efficacy, work with } \\
\text { provider, handle } \\
\text { fluctuations in } \\
\text { disease/treatment, } \\
\text { communicating with } \\
\text { others about } \\
\text { disease, intimate } \\
\text { relationships, having } \\
\text { children. }\end{array}$ & N/A \\
\hline $\begin{array}{l}\text { Been- } \\
\text { Dahmen, } \\
2015\end{array}$ & $\begin{array}{l}\text { Nether- } \\
\text { lands }\end{array}$ & Qualitative & $\begin{array}{c}\text { Outpatient } \\
\text { nurses }\end{array}$ & $\begin{array}{l}\text { Outpatient } \\
\text { nurses }\end{array}$ & $\begin{array}{l}\text { Adults with } \\
\text { chronic } \\
\text { conditions }\end{array}$ & $\begin{array}{l}\text { Chronic } \\
\text { care model }\end{array}$ & $\begin{array}{l}\text { Having a chronic } \\
\text { condition, } \\
\text { attending a } \\
\text { clinic where } \\
\text { SMS provided }\end{array}$ & $\begin{array}{l}\text { Education on } \\
\text { adhering to a } \\
\text { medical regimen; } \\
\text { monitoring } \\
\text { symptoms; and } \\
\text { integrating illness } \\
\text { into daily life. }\end{array}$ & N/A \\
\hline
\end{tabular}

This is the author's manuscript of the work published in final edited form as:

Tanner, A., von Gaudecker, J., Buelow, J. \& Miller, W. Hybrid concept analysis of self-management support: School nurses supporting students with psychogenic nonepileptic seizures. Journal of School Nursing. 


\begin{tabular}{|c|c|c|c|c|c|c|c|c|c|}
\hline $\begin{array}{l}\text { First } \\
\text { Author, } \\
\text { Year }\end{array}$ & Country & Design & $\begin{array}{l}\text { Discipline/ } \\
\text { Setting }\end{array}$ & SMS Delivery & Population & Theory & $\begin{array}{l}\text { Antecedents of } \\
\text { SMS }\end{array}$ & Attributes of SMS & $\begin{array}{l}\text { Consequences } \\
\text { of SMS }\end{array}$ \\
\hline $\begin{array}{c}\text { Cahill, } \\
2016\end{array}$ & US & $\begin{array}{l}\text { Scoping } \\
\text { review }\end{array}$ & $\begin{array}{c}\text { Occupa- } \\
\text { tional } \\
\text { therapy }\end{array}$ & $\mathrm{N} / \mathrm{A}$ & $\begin{array}{l}\text { Children } \\
\text { (age 8- } \\
19)\end{array}$ & $\mathrm{N} / \mathrm{A}$ & $\begin{array}{l}\text { Child having } \\
\text { diabetes }\end{array}$ & $\begin{array}{l}\text { Parent involvement, } \\
\text { use of technology, } \\
\text { shift of parent- } \\
\text { management to self- } \\
\text { management of child }\end{array}$ & $\begin{array}{l}\text { Increased } \\
\text { adherence to } \\
\text { self- } \\
\text { management } \\
\text { routines, use } \\
\text { of SM skills, } \\
\text { and parent } \\
\text { perception of } \\
\text { child's ability } \\
\text { to carry out } \\
\text { SM, }\end{array}$ \\
\hline $\begin{array}{c}\text { Dwars- } \\
\text { waard, } \\
2015\end{array}$ & $\begin{array}{l}\text { Nether- } \\
\text { lands }\end{array}$ & Qualitative & Nurses & Nurses & $\begin{array}{l}\text { In-/out- } \\
\text { patient, } \\
\text { home } \\
\text { care of } \\
\text { adults } \\
\text { and } \\
\text { children }\end{array}$ & $\mathrm{N} / \mathrm{A}$ & $\begin{array}{l}\text { Nurse being able } \\
\text { to relinquish } \\
\text { some control } \\
\text { and balance } \\
\text { ethical dilemma } \\
\text { of patient } \\
\text { autonomy at the } \\
\text { risk of power } \\
\text { health } \\
\text { outcomes. }\end{array}$ & $\begin{array}{l}\text { Offering patients } \\
\text { choices, taking on } \\
\text { management tasks } \\
\text { when patient prefers } \\
\text { to remain passive, } \\
\text { becoming involved in } \\
\text { patients' private lives. }\end{array}$ & $\begin{array}{l}\text { Medical } \\
\text { outcomes, } \\
\text { quality of life, } \\
\text { relates to the } \\
\text { way self- } \\
\text { management } \\
\text { is conceptu- } \\
\text { alized }\end{array}$ \\
\hline $\begin{array}{l}\text { Henry, } \\
2015\end{array}$ & US & $\begin{array}{l}\text { Informa- } \\
\text { tion report }\end{array}$ & $\begin{array}{l}\text { Pediatric } \\
\text { medicine }\end{array}$ & $\mathrm{N} / \mathrm{A}$ & Pediatric & $\mathrm{N} / \mathrm{A}$ & $\mathrm{N} / \mathrm{A}$ & $\begin{array}{l}\text { Providing } \\
\text { patient/family with } \\
\text { written materials, call } \\
\text { back hotlines for } \\
\text { advice, email } \\
\text { communication with } \\
\text { parents, medical/ } \\
\text { role/emotional } \\
\text { management, day-to- } \\
\text { day/family } \\
\text { functioning support. } \\
\text { Involves child, } \\
\text { parent, health care } \\
\text { provider. }\end{array}$ & $\begin{array}{l}\text { Improved } \\
\text { health } \\
\text { outcomes, } \\
\text { reduced } \\
\text { inappropriate } \\
\text { healthcare } \\
\text { utilization, } \\
\text { healthcare } \\
\text { cost, care- } \\
\text { giver burden, } \\
\text { decreased } \\
\text { absenteeism } \\
\text { from } \\
\text { school/work, }\end{array}$ \\
\hline
\end{tabular}




\begin{tabular}{|c|c|c|c|c|c|c|c|c|c|}
\hline $\begin{array}{l}\text { First } \\
\text { Author, } \\
\text { Year }\end{array}$ & Country & Design & $\begin{array}{l}\text { Discipline/ } \\
\text { Setting }\end{array}$ & SMS Delivery & Population & Theory & $\begin{array}{l}\text { Antecedents of } \\
\text { SMS }\end{array}$ & Attributes of SMS & $\begin{array}{l}\text { Consequences } \\
\text { of SMS }\end{array}$ \\
\hline & & & & & & & & & $\begin{array}{l}\text { improved } \\
\text { parental QOL. }\end{array}$ \\
\hline $\begin{array}{l}\text { Hommel, } \\
2015\end{array}$ & US & $\begin{array}{c}\text { Study } \\
\text { protocol } \\
\text { multisite } \\
\text { RCT }\end{array}$ & $\begin{array}{l}\text { Recruit- } \\
\text { ment at } \\
\text { large } \\
\text { children's } \\
\text { hospitals' } \\
\text { gastro- } \\
\text { enterology } \\
\text { clinics }\end{array}$ & $\begin{array}{l}\text { Telehealth } \\
\text { video } \\
\text { conferencing } \\
\text { by } \\
\text { graduate/post } \\
\text { grad } \\
\text { psychology } \\
\text { students }\end{array}$ & $\begin{array}{l}\text { Children } \\
\text { 11-18 } \\
\text { with } \\
\text { inflamma- } \\
\text { tory bowel } \\
\text { disease }\end{array}$ & $\begin{array}{l}\text { None } \\
\text { specified }\end{array}$ & $\begin{array}{l}\text { Receive } \\
\text { technology tools } \\
\text { and training on } \\
\text { how to use } \\
\text { them }\end{array}$ & $\begin{array}{l}\text { Education, targeting } \\
\text { barriers to } \\
\text { medication } \\
\text { adherence, family } \\
\text { adherence goal } \\
\text { setting, family } \\
\text { selected plan to meet } \\
\text { goal, responsibility of } \\
\text { each individual to } \\
\text { reach goal, reward } \\
\text { for adolescent if goal } \\
\text { met, follow up phone } \\
\text { call in a week to see } \\
\text { if goal met and re- } \\
\text { implement plan if } \\
\text { goal not met. }\end{array}$ & $\mathrm{N} / \mathrm{A}$ \\
\hline $\begin{array}{l}\text { Krieger, } \\
2009\end{array}$ & US & $\mathrm{RCT}$ & In-home & $\begin{array}{l}\text { Community } \\
\text { health worker } \\
\text { at home vs. } \\
\text { Nurse at clinic } \\
\text { only }\end{array}$ & $\begin{array}{l}\text { Household } \\
\text { with child } \\
3-13 \text { with } \\
\text { poorly } \\
\text { controlled } \\
\text { asthma }\end{array}$ & $\begin{array}{l}\text { Social } \\
\text { cognitive } \\
\text { theory; } \\
\text { transtheor } \\
\text { etical } \\
\text { stages of } \\
\text { the change } \\
\text { model }\end{array}$ & $\begin{array}{l}\text { Household has } \\
\text { child with } \\
\text { asthma; } \\
\text { connection with } \\
\text { CHW }\end{array}$ & $\begin{array}{l}\text { Education, supplied } \\
\text { resources, goal } \\
\text { setting and progress } \\
\text { monitoring }\end{array}$ & $\begin{array}{l}\text { Number of } \\
\text { symptom-free } \\
\text { days, care- } \\
\text { taker QOL, } \\
\text { trigger } \\
\text { prevention } \\
\text { behaviors, } \\
\text { improved } \\
\text { medication } \\
\text { adherence }\end{array}$ \\
\hline $\begin{array}{l}\text { Lozano, } \\
2018\end{array}$ & US & $\begin{array}{c}\text { Informa- } \\
\text { tional } \\
\text { report }\end{array}$ & $\begin{array}{l}\text { Pediatric } \\
\text { medicine }\end{array}$ & N/A & $\begin{array}{l}\text { Children } \\
\text { and } \\
\text { families }\end{array}$ & $\begin{array}{l}\text { Pediatric } \\
\text { self- } \\
\text { manage- } \\
\text { ment } \\
\text { model, } \\
\text { Interna- } \\
\text { tional } \\
\text { Class. of }\end{array}$ & $\begin{array}{l}\text { Health care } \\
\text { provider } \\
\text { understanding } \\
\text { of child } \\
\text { dependency on } \\
\text { parent, } \\
\text { developmental } \\
\text { stage of child }\end{array}$ & $\begin{array}{l}\text { Services that health } \\
\text { systems and } \\
\text { community agencies } \\
\text { provide to those with } \\
\text { chronic illness and } \\
\text { their families to } \\
\text { facilitate self- } \\
\text { management; }\end{array}$ & $\mathrm{N} / \mathrm{A}$ \\
\hline
\end{tabular}




\begin{tabular}{|c|c|c|c|c|c|c|c|c|c|}
\hline $\begin{array}{l}\text { First } \\
\text { Author, } \\
\text { Year }\end{array}$ & Country & Design & $\begin{array}{l}\text { Discipline/ } \\
\text { Setting }\end{array}$ & SMS Delivery & Population & Theory & $\begin{array}{l}\text { Antecedents of } \\
\text { SMS }\end{array}$ & Attributes of SMS & $\begin{array}{l}\text { Consequences } \\
\text { of SMS }\end{array}$ \\
\hline & & & & & & $\begin{array}{l}\text { Function- } \\
\text { ing } \\
\text { Disability } \\
\text { and Health }\end{array}$ & $\begin{array}{l}\text { with resulting } \\
\text { readiness for } \\
\text { role in SM, } \\
\text { Child intrinsic } \\
\text { capacity as well } \\
\text { as performance } \\
\text { ability. }\end{array}$ & $\begin{array}{l}\text { collaboration } \\
\text { between the patient, } \\
\text { family, and care } \\
\text { providers. }\end{array}$ & \\
\hline $\begin{array}{l}\text { Marjolijn, } \\
2016\end{array}$ & $\begin{array}{l}\text { Nether- } \\
\text { lands }\end{array}$ & $\begin{array}{l}\text { Systematic } \\
\text { review }\end{array}$ & $\begin{array}{l}\text { Inpatient/o } \\
\text { utpatient } \\
\text { clinics, } \\
\text { home, } \\
\text { online, } \\
\text { school, } \\
\text { camping } \\
\text { sites }\end{array}$ & $\begin{array}{l}\text { Mono- } \\
\text { disciplinary }\end{array}$ & $\begin{array}{l}\text { Youth with } \\
\text { chronic } \\
\text { conditions } \\
\text { (age 7- } \\
25 \text { ) }\end{array}$ & $\begin{array}{l}\text { Bandura's } \\
\text { (cognitive) } \\
\text { social } \\
\text { learning } \\
\text { theory, } \\
\text { cognitive } \\
\text { behavioral } \\
\text { theory. }\end{array}$ & $\begin{array}{l}\text { Presence of a } \\
\text { chronic } \\
\text { condition, need } \\
\text { for transition } \\
\text { from parent } \\
\text { control of care } \\
\text { to child control } \\
\text { of care }\end{array}$ & $\begin{array}{l}\text { Medical, role, and } \\
\text { emotion } \\
\text { management; } \\
\text { education, peer- } \\
\text { support, problem } \\
\text { solving, relaxation } \\
\text { training, cognitive } \\
\text { restructuring }\end{array}$ & $\begin{array}{l}\text { Disease } \\
\text { knowledge, } \\
\text { adherence, } \\
\text { but not } \\
\text { symptom } \\
\text { severity or } \\
\text { school } \\
\text { attendance. }\end{array}$ \\
\hline $\begin{array}{l}\text { Morrison, } \\
2014\end{array}$ & $\begin{array}{l}\text { United } \\
\text { Kingdom }\end{array}$ & $\begin{array}{c}\text { Systematic } \\
\text { review }\end{array}$ & & Digital & $\begin{array}{l}\text { Adults and } \\
\text { children } \\
\text { with } \\
\text { asthma }\end{array}$ & $\begin{array}{l}\text { None } \\
\text { specified }\end{array}$ & $\begin{array}{l}\text { Having asthma } \\
\text { or being } \\
\text { caregiver of } \\
\text { someone with } \\
\text { asthma }\end{array}$ & $\begin{array}{l}\text { Education, providing } \\
\text { advice, behavior } \\
\text { change approach }\end{array}$ & $\begin{array}{l}\text { Improved } \\
\text { markers of } \\
\text { self-care, } \\
\text { QOL, } \\
\text { medication } \\
\text { use }\end{array}$ \\
\hline $\begin{array}{c}\text { Sattoe, } \\
2015\end{array}$ & $\begin{array}{l}\text { Nether- } \\
\text { lands }\end{array}$ & $\begin{array}{l}\text { Systematic } \\
\text { review }\end{array}$ & $\begin{array}{l}\text { Camp, } \\
\text { inpatient, } \\
\text { outpatient, } \\
\text { school, } \\
\text { online }\end{array}$ & $\begin{array}{l}\text { Pediatricians, } \\
\text { nurses, } \\
\text { physiotherapist } \\
\text { s, occupational } \\
\text { therapists, } \\
\text { psychologists, } \\
\text { social workers, } \\
\text { pedagogues, } \\
\text { dietitians, job } \\
\text { coaches, and } \\
\text { speech } \\
\text { pathologists }\end{array}$ & $\begin{array}{l}\text { Young } \\
\text { people 7- } \\
25 \text { with } \\
\text { chronic } \\
\text { disease }\end{array}$ & $N / A$ & N/A & $\begin{array}{l}\text { More often aimed at } \\
\text { individual or } \\
\text { individual and group, } \\
\text { involved education } \\
\text { and/or skills training, } \\
\text { parents included in } \\
1 / 4 . \text { Medical, role, } \\
\text { and emotion/identity } \\
\text { management. }\end{array}$ & $\begin{array}{l}\text { Medical } \\
\text { outcomes, } \\
\text { health-related } \\
\text { QOL, } \\
\text { knowledge } \\
\text { about the } \\
\text { disease/treat- } \\
\text { ment. }\end{array}$ \\
\hline $\begin{array}{c}\text { Shomaker, } \\
2016\end{array}$ & US & $\begin{array}{l}\text { Feasibility } \\
\text { study }\end{array}$ & $\begin{array}{l}\text { Asthma } \\
\text { clinic }\end{array}$ & $\begin{array}{l}12 \text { topic } \\
\text { worksheet }\end{array}$ & $\begin{array}{l}\text { Children } \\
\text { (age 1- } \\
18)\end{array}$ & $\begin{array}{l}\text { Behavior } \\
\text { change } \\
\text { theory and }\end{array}$ & $\begin{array}{l}\text { Child with } \\
\text { asthma, self- } \\
\text { efficacy }\end{array}$ & $\begin{array}{l}\text { Education on patient- } \\
\text { centered topic } \\
\text { preferences, goal }\end{array}$ & $\begin{array}{l}\text { Patient- } \\
\text { centered }\end{array}$ \\
\hline
\end{tabular}




\begin{tabular}{|c|c|c|c|c|c|c|c|c|c|}
\hline $\begin{array}{l}\text { First } \\
\text { Author, } \\
\text { Year }\end{array}$ & Country & Design & $\begin{array}{l}\text { Discipline/ } \\
\text { Setting }\end{array}$ & SMS Delivery & Population & Theory & $\begin{array}{l}\text { Antecedents of } \\
\text { SMS }\end{array}$ & Attributes of SMS & $\begin{array}{l}\text { Consequences } \\
\text { of SMS }\end{array}$ \\
\hline & & & & & & $\begin{array}{l}\text { motivation } \\
\text { al } \\
\text { interviewin } \\
\mathrm{g} \\
\text { techniques }\end{array}$ & $\begin{array}{l}\text { perception of at } \\
\text { least moderate } \\
\text { level }\end{array}$ & $\begin{array}{l}\text { setting, follow up } \\
\text { phone call. }\end{array}$ & $\begin{array}{l}\text { preference } \\
\text { goals met }\end{array}$ \\
\hline $\begin{array}{l}\text { Sinoo, } \\
2018\end{array}$ & $\begin{array}{l}\text { Nether- } \\
\text { lands }\end{array}$ & $\begin{array}{l}\text { Feasibility } \\
\text { study }\end{array}$ & $\begin{array}{l}\text { Home/ } \\
\text { camp }\end{array}$ & $\begin{array}{l}\text { Digital game } \\
\text { app with avatar } \\
\text { vs. robot }\end{array}$ & $\begin{array}{l}\text { Children } \\
\text { (age 8- } \\
\text { 11) at } \\
\text { diabetes } \\
\text { camp }\end{array}$ & $\begin{array}{l}\text { Self- } \\
\text { determi- } \\
\text { nation } \\
\text { theory }\end{array}$ & $\begin{array}{l}\text { Have diabetes, } \\
\text { develop a } \\
\text { friendship/conn } \\
\text { ection with } \\
\text { educator (robot } \\
\text { and avatar) }\end{array}$ & $\begin{array}{l}\text { Education on disease } \\
\text { and self- } \\
\text { management skills }\end{array}$ & N/A \\
\hline $\begin{array}{l}\text { van Bragt, } \\
2015\end{array}$ & $\begin{array}{l}\text { Nether- } \\
\text { lands }\end{array}$ & $\begin{array}{l}\text { Cluster- } \\
\text { RCT }\end{array}$ & $\begin{array}{c}\text { Primary } \\
\text { care and } \\
\text { specialized } \\
\text { care } \\
\text { outpatient } \\
\text { clinics }\end{array}$ & $\begin{array}{l}\text { Outpatient } \\
\text { nurses }\end{array}$ & $\begin{array}{l}\text { Children } \\
\text { (age 6- } \\
11 \text { ) }\end{array}$ & $\begin{array}{l}\text { Theory of } \\
\text { behavior } \\
\text { change } \\
\text { and shared } \\
\text { decision } \\
\text { making }\end{array}$ & $\begin{array}{l}\text { Having asthma } \\
\text { and coming to } \\
\text { clinic for routine } \\
\text { care }\end{array}$ & $\begin{array}{l}\text { Shared goal setting, } \\
\text { written action plan, } \\
\text { follow up to check on } \\
\text { effectiveness of } \\
\text { written plan }\end{array}$ & Improved QOL \\
\hline $\begin{array}{c}\text { van Hooft, } \\
2017\end{array}$ & $\begin{array}{l}\text { Nether- } \\
\text { lands }\end{array}$ & $\begin{array}{l}\text { Realist } \\
\text { review }\end{array}$ & Outpatient & Nurses & $\begin{array}{l}\text { Adults with } \\
\text { chronic } \\
\text { conditions }\end{array}$ & $\begin{array}{l}\text { Several } \\
\text { theories } \\
\text { noted in } \\
\text { studies } \\
\text { examined }\end{array}$ & $\begin{array}{l}\text { Need for } \\
\text { knowledge, } \\
\text { behavior } \\
\text { change, coping, } \\
\text { motivation, or } \\
\text { self-efficacy for } \\
\text { chronic disease }\end{array}$ & $\begin{array}{l}\text { Multidisciplinary } \\
\text { approach, coach } \\
\text { patients }\end{array}$ & $\begin{array}{l}\text { Motivation/self- } \\
\text { efficacy, } \\
\text { behavioral } \\
\text { change }\end{array}$ \\
\hline \multicolumn{10}{|c|}{ SMS for Mental Health Conditions } \\
\hline $\begin{array}{l}\text { Brooks, } \\
2016\end{array}$ & $\begin{array}{l}\text { United } \\
\text { Kingdom }\end{array}$ & $\begin{array}{l}\text { Qualitative } \\
\text { and social } \\
\text { network } \\
\text { mapping }\end{array}$ & Home & Pet & $\begin{array}{l}\text { Adults with } \\
\text { severe } \\
\text { chronic } \\
\text { mental } \\
\text { health } \\
\text { condition }\end{array}$ & $\begin{array}{l}\text { Corbin and } \\
\text { Strauss's } \\
\text { notion of } \\
\text { illness } \\
\text { 'work' }\end{array}$ & $\begin{array}{l}\text { Ability to own } \\
\text { and care for pet }\end{array}$ & $\begin{array}{l}\text { Care of pet, } \\
\text { relationship with pet, } \\
\text { physical contact with } \\
\text { pet }\end{array}$ & $\begin{array}{l}\text { Perceived } \\
\text { support from } \\
\text { pet }\end{array}$ \\
\hline $\begin{array}{l}\text { Hensel, } \\
2016\end{array}$ & Canada & $\begin{array}{l}\text { Study } \\
\text { protocol of } \\
\text { RCT }\end{array}$ & $\begin{array}{l}\text { Telehealth } \\
\text { organiza- } \\
\text { tion }\end{array}$ & Online program & $\begin{array}{l}\text { Adults (16 } \\
\text { and older) }\end{array}$ & $\begin{array}{l}\text { Novel } \\
\text { model of } \\
\text { integrated }\end{array}$ & $\begin{array}{l}\text { Motivation to do } \\
\text { the work of CBT }\end{array}$ & $\begin{array}{l}\text { peer support, CBT } \\
\text { therapy intervention } \\
\text { that involves } \\
\text { identifying }\end{array}$ & N/A \\
\hline
\end{tabular}




\begin{tabular}{|c|c|c|c|c|c|c|c|c|c|}
\hline $\begin{array}{l}\text { First } \\
\text { Author, } \\
\text { Year }\end{array}$ & Country & Design & $\begin{array}{l}\text { Discipline/ } \\
\text { Setting }\end{array}$ & SMS Delivery & Population & Theory & $\begin{array}{l}\text { Antecedents of } \\
\text { SMS }\end{array}$ & Attributes of SMS & $\begin{array}{l}\text { Consequences } \\
\text { of SMS }\end{array}$ \\
\hline & & & & & & $\begin{array}{l}\text { knowledge } \\
\text { translation }\end{array}$ & & $\begin{array}{l}\text { dysfunctional } \\
\text { thinking, examine } \\
\text { validity and } \\
\text { usefulness of } \\
\text { thoughts, test } \\
\text { accuracy of } \\
\text { predictions }\end{array}$ & \\
\hline $\begin{array}{l}\text { Ludman, } \\
2016\end{array}$ & US & $\mathrm{RCT}$ & $\begin{array}{l}\text { Phone or } \\
\text { face-to- } \\
\text { face } \\
\text { meetings }\end{array}$ & $\begin{array}{l}\text { Therapist and } \\
\text { trained peer } \\
\text { specialist }\end{array}$ & $\begin{array}{l}\text { Adults with } \\
\text { chronic or } \\
\text { recurrent } \\
\text { depres- } \\
\text { sive } \\
\text { symptoms }\end{array}$ & $\begin{array}{l}\text { chronic } \\
\text { care } \\
\text { model, } \\
\text { recovery } \\
\text { model }\end{array}$ & $\begin{array}{l}\text { Identification by } \\
\text { healthcare } \\
\text { provider as a } \\
\text { person with a } \\
\text { condition that } \\
\text { may benefit } \\
\text { from SMS }\end{array}$ & $\begin{array}{l}\text { Multiple approaches } \\
\text { from different models } \\
\text { of care, flexibility as } \\
\text { patient-centered }\end{array}$ & $\begin{array}{l}\text { Decrease in } \\
\text { depressive } \\
\text { symptoms/ep- } \\
\text { isodes, } \\
\text { patient-rated } \\
\text { global } \\
\text { improvement, } \\
\text { and } \\
\text { perception of } \\
\text { recovery }\end{array}$ \\
\hline $\begin{array}{c}\text { McCusker, } \\
2017\end{array}$ & Canada & $\begin{array}{l}\text { Validation } \\
\text { of tests }\end{array}$ & $\begin{array}{l}\text { Primary } \\
\text { care }\end{array}$ & $\begin{array}{l}\text { Non- } \\
\text { psychologist } \\
\text { coach }\end{array}$ & $\begin{array}{l}\text { Adults with } \\
\text { physical } \\
\text { chronic } \\
\text { condition } \\
\text { and } \\
\text { comorbid } \\
\text { mental } \\
\text { health } \\
\text { concern }\end{array}$ & $\begin{array}{l}\text { Item } \\
\text { response } \\
\text { theory }\end{array}$ & $\begin{array}{l}\text { Healthcare } \\
\text { provider } \\
\text { recognizing } \\
\text { mental health } \\
\text { concern, having } \\
\text { competence/ } \\
\text { confidence to } \\
\text { provide SMS for } \\
\text { physical and } \\
\text { emotional/mood } \\
\text { conditions }\end{array}$ & $\begin{array}{l}\text { Address adherence to } \\
\text { treatment, coping } \\
\text { with minor } \\
\text { complications, } \\
\text { impact of the health } \\
\text { condition, how/why } \\
\text { to do treatments, } \\
\text { required } \\
\text { monitoring/visits, } \\
\text { discussion of } \\
\text { personal goals and } \\
\text { how to reach them }\end{array}$ & N/A \\
\hline $\begin{array}{l}\text { Milton, } \\
2017\end{array}$ & $\begin{array}{l}\text { United } \\
\text { Kingdom }\end{array}$ & $\begin{array}{l}\text { Pilot of } \\
\text { interven- } \\
\text { tion }\end{array}$ & $\begin{array}{c}\text { Mental } \\
\text { health/ } \\
\text { home/ } \\
\text { outpatient }\end{array}$ & $\begin{array}{l}\text { Peer support } \\
\text { worker who } \\
\text { has } \\
\text { experienced } \\
\text { mental health } \\
\text { condition }\end{array}$ & $\begin{array}{l}\text { Adults } \\
\text { post- } \\
\text { mental } \\
\text { health } \\
\text { crisis } \\
\text { necessita- }\end{array}$ & $\mathrm{N} / \mathrm{A}$ & $\begin{array}{l}\text { Experience } \\
\text { mental health } \\
\text { crisis, commit to } \\
\text { ten-week } \\
\text { program, } \\
\text { welcome peer } \\
\text { interventionist, }\end{array}$ & $\begin{array}{l}\text { Learn to monitor } \\
\text { warning signs of } \\
\text { mental health crisis, } \\
\text { develop coping } \\
\text { strategies, and } \\
\text { identify help } \\
\text { resources }\end{array}$ & $\mathrm{N} / \mathrm{A}$ \\
\hline
\end{tabular}




\begin{tabular}{|c|c|c|c|c|c|c|c|c|c|}
\hline $\begin{array}{l}\text { First } \\
\text { Author, } \\
\text { Year }\end{array}$ & Country & Design & $\begin{array}{l}\text { Discipline/ } \\
\text { Setting }\end{array}$ & SMS Delivery & Population & Theory & $\begin{array}{l}\text { Antecedents of } \\
\text { SMS }\end{array}$ & Attributes of SMS & $\begin{array}{l}\text { Consequences } \\
\text { of SMS }\end{array}$ \\
\hline & & & & & $\begin{array}{l}\text { ting acute } \\
\text { care }\end{array}$ & & $\begin{array}{l}\text { reading level } \\
\text { that matches } \\
\text { workbook }\end{array}$ & & \\
\hline $\begin{array}{c}\text { Sharpe, } \\
2017\end{array}$ & $\begin{array}{l}\text { United } \\
\text { Kingdom }\end{array}$ & $\mathrm{RCT}$ & School & $\begin{array}{l}\text { Booklet, } \\
\text { information on } \\
\text { how booklets } \\
\text { distributed or } \\
\text { used with } \\
\text { student not } \\
\text { collected by } \\
\text { researchers }\end{array}$ & $\begin{array}{l}\text { School } \\
\text { children } \\
\text { (age 10- } \\
13 \text { ) }\end{array}$ & $N / A$ & $\begin{array}{l}\text { Receipt of } \\
\text { booklet, ability } \\
\text { to read booklet, } \\
\text { booklet } \\
\text { matching } \\
\text { readers' reading } \\
\text { level }\end{array}$ & $\begin{array}{l}\text { Psychoeducation, } \\
\text { mental health } \\
\text { awareness, CBT } \\
\text { concepts }\end{array}$ & $\begin{array}{l}\text { No difference } \\
\text { seen in } \\
\text { intervention } \\
\text { group. } \\
\text { Booklets } \\
\text { without some } \\
\text { measure of } \\
\text { how into use } \\
\text { not beneficial } \\
\text { for mental } \\
\text { health } \\
\text { outcomes. }\end{array}$ \\
\hline
\end{tabular}


Table 2

Hybrid conceptual analysis findings in Theoretical and Fieldwork Phases

\begin{tabular}{|c|c|c|}
\hline $\begin{array}{l}\text { Definition- } \\
\text { Informing } \\
\text { Source }\end{array}$ & Phase 1: Theoretical Phase & Phase 2: Fieldwork Phase \\
\hline $\begin{array}{l}\text { Implicit } \\
\text { definition/ } \\
\text { attribute }\end{array}$ & & \\
\hline Behavioral & $\begin{array}{l}\text { - Goal-setting (Krieger et al., 2009; Shomaker \& DeVeau-Rosen, 2016) } \\
\text {-shared (Van Bragt et al., 2015) } \\
\text {-patient-focused (Henry \& Schor, 2015) } \\
\text { - Communicating responsibility of each person to reach goals, rewarding } \\
\text { patients when goals are met, and re-implementing a plan if a goal is not met } \\
\text { (Hommel et al., 2015) } \\
\text { - Writing action plans (Van Bragt et al., 2015) } \\
\text {-technologically recorded/conveyed (Cahill et al., 2016; Henry \& Schor, } \\
\text { 2015) } \\
\text { - Progress monitoring (Krieger et al., 2009) } \\
\text {-via follow-up phone calls (Shomaker \& DeVeau-Rosen, 2016) } \\
\text {-via "check-ins" on effectiveness of a written plan (Hommel et al., 2015; Van } \\
\text { Bragt et al., 2015) } \\
\text {-for warning signs of mental health crisis warranting help resources (Milton } \\
\text { et al., 2017) } \\
\text { - Coaching (Henry \& Schor, 2015; van Hooft et al., 2017) } \\
\text {-for behavior change (Morrison et al., 2014) } \\
\text {-through problem solving and relaxation training (Marjolijn et al., 2016) } \\
\text {-for self-management skills (Sattoe et al., 2015; Sinoo et al., 2018) } \\
\text {-for coping strategies (Milton et al., 2017) } \\
\text {-for self-efficacy (Ammerlaan et al., 2017) } \\
\text {-through administering cognitive behavioral therapy (Hensel et al., 2016; }\end{array}$ & $\begin{array}{l}\text { Developing plan } \\
\text {-exploring options } \\
\text {-using Likert-type scale for student- } \\
\text { reported anxiety } \\
\text {-setting boundaries } \\
\text {-participating in 504/IEP plan meetings } \\
\text {-facilitating "time out" opportunities } \\
\text {-ensuring extra time for assignments } \\
\text {-involving student, parent, teacher, and } \\
\text { school personnel } \\
\text { - Coaching } \\
\text {-for student-teacher communication } \\
\text {-making healthy choices } \\
\text {-through plan evaluation } \\
\text { - Communicating } \\
\text {-plan details from provider } \\
\text {-triggers for PNES events } \\
\text {-effective de-escalation strategies } \\
\text {-with parents about effectiveness of } \\
\text { self-management activities } \\
\text {-with student, parents, and school } \\
\text { personnel to debrief after PNES event }\end{array}$ \\
\hline
\end{tabular}

Sharpe et al., 2017)

-to shift from parent-management to self-management by child (Cahill et al., 2016) 


\section{Definition- \\ Informing \\ Source}

Educational

\section{Phase 1: Theoretical Phase}

- Educating and assessing knowledge (Been-Dahmen et al., 2015; Henry \& Schor, 2015; Hommel et al., 2015; Krieger et al., 2009; Marjolijn et al., 2016; Morrison et al., 2014; Sattoe et al., 2015; Sinoo et al., 2018) - informing of community resources (Krieger et al., 2009) -providing patient/family with written materials (Henry \& Schor, 2015) -providing advice (Henry \& Schor, 2015; Morrison et al., 2014) -offering psychoeducation (Sharpe et al., 2017)

-promoting mental health awareness through age-appropriate booklets for all students in school (Sharpe et al., 2017)

Psychosocial - Training in emotion/identity management (Henry \& Schor, 2015; Marjolijn et al., 2016; Sattoe et al., 2015) and cognitive restructuring (Marjolijn et al., 2016)

- Exploring one's role in society with condition (Henry \& Schor, 2015; Marjolijn et al., 2016; Sattoe et al., 2015)

- Facilitating peer support, often in group setting (Henry \& Schor, 2015; Hensel et al., 2016; Marjolijn et al., 2016)

- involving peer community health workers or specialists (Ammerlaan et al., 2017; Ludman et al., 2016; Milton et al., 2017) or expert patients as trainers (Ammerlaan et al., 2017)

- Involving parent (Cahill et al., 2016; Sattoe et al., 2015)

-communicating via email (Henry \& Schor, 2015)

-creating plan with parent-involvement (Hommel et al., 2015)

-informing how to communicate with provider (Ammerlaan et al., 2017)

-improving communication/collaboration between child, parent, and provider (Henry \& Schor, 2015; Lozano \& Houtrow, 2018)

- Including day-to-day life and family functioning support (Henry \& Schor, 2015)

-Addressing patient's stage of life, intimate relationships, and reproduction (Ammerlaan et al., 2017)

-Practicing telling peers and co-workers about condition and attendance concerns (Ammerlaan et al., 2017)

-Incorporating pets into therapeutic plan (Brooks et al., 2016)

Clinical
- Integrating medical treatment of condition (Henry \& Schor, 2015; Marjolijn et al., 2016; Sattoe et al., 2015)
Phase 2: Fieldwork Phase

- Educating and assessing knowledge of student and parent

-sharing information

-providing tools

-using written plan from provider to provide one-on-one education with student

-educating teachers and school personnel about PNES

- Building skills and relationships to support self-advocacy -balancing parent concern and student desire for "freedom"

-fostering trust of school nurse's ability to manage and student's ability to selfmanage PNES

- Providing a safe place -practicing coping skills after experiencing seizure warning -practicing/visualizing steps to use when experiencing increased stress/anxiety

- Integrating mental health care 


\section{Definition- \\ Informing}

Source

- monitoring symptoms (Been-Dahmen et al., 2015)

- handling fluctuations in disease and treatment (Ammerlaan et al., 2017)

-targeting barriers to medication adherence (Hommel et al., 2015)

-considering state of disease process (Ammerlaan et al., 2017)

-setting goal for family adherence (Hommel et al., 2015)

\section{Measurements - SMInfo-Mood and CP-Mood (McCusker et al., 2017)}

- behavioral ("staying healthy", "improving health", how to "do treatments", and "discussion of personal goals and how to reach them")

- educational ("helpfulness of information received on adhering to

treatment", "explanations about impact of the health condition")

- psychosocial ("coping with minor complications")

- clinical (why to "do treatments", "required monitoring", and "visits with other health professionals")

\section{Antecedents Patient/family:}

- Attending a clinic/setting where the opportunity for SMS is offered (BeenDahmen et al., 2015)

- Returning to a clinic for routine care that may coincide with SMS (Van Bragt et al., 2015)

- Receiving technology tools and appropriate training on how to use them (Hommel et al., 2015)

- Reading at a level that matches written materials (Milton et al., 2017; Sharpe et al., 2017)

- Needing knowledge, behavior change, coping skills, motivation, or selfefficacy (van Hooft et al., 2017)

- Needing transition of control of care from parent to child (Marjolijn et al., 2016)

- Connection with coach, trainer, provider, or robot/avatar (Krieger et al., 2009; Milton et al., 2017; Sinoo et al., 2018)

Phase 2: Fieldwork Phase

-Seeking appropriate mental health

care

-Keeping mental health care

appointments

-Acquiring medications to treat comorbid conditions

-Communicating with health care

provider about tools to support student at school

- No instrument for SMS noted

- Identified indicators of successful SMS

-willingness to participate in SMS -confidence in self-managing PNES -participation in mental health care -advocating for self -teacher understanding of the condition

\section{Patient/family:}

- Receiving care of mental health care provider with confirmed PNES diagnosis

- Obtaining health care action plan from provider for school use

- Demonstrating poor selfmanagement/poor school attendance

- Student- and family-readiness to receive SMS 


\begin{tabular}{|c|c|c|}
\hline $\begin{array}{l}\text { Definition- } \\
\text { Informing } \\
\text { Source }\end{array}$ & Phase 1: Theoretical Phase & Phase 2: Fieldwork Phase \\
\hline & $\begin{array}{l}\text { - Sufficient self-efficacy perception (at least moderate level of belief goals can } \\
\text { be met; Shomaker \& DeVeau-Rosen, 2016) } \\
\text { - Internal motivation to do necessary work (Hensel et al., 2016) and } \\
\text { commitment to lengthy program (Milton et al., 2017) }\end{array}$ & \\
\hline & $\begin{array}{l}\text { Provider: } \\
\text { - Ability to recognize a health concern that would benefit from SMS (Ludman } \\
\text { et al., 2016; McCusker et al., 2017) } \\
\text { - Understanding child's dependency on parents and the developmental stage } \\
\text { of the child (Ludman et al., 2016; McCusker et al., 2017) } \\
\text { - Competence and confidence in ability to provide SMS based on patients' } \\
\text { content and structure preferences (Ammerlaan et al., 2017; McCusker et al., } \\
\text { 2017) }\end{array}$ & $\begin{array}{l}\text { School Nurse: } \\
\text { - Confidence in presenting material } \\
\text { about condition } \\
\text { - Expectance of positive outcomes }\end{array}$ \\
\hline Consequences & $\begin{array}{l}\text { - Decrease in symptom-free days (Krieger et al., 2009) } \\
\text { - Improved care giver and patient QOL (Krieger et al., 2009; Morrison et al., } \\
\text { 2014; Sattoe et al., 2015; Van Bragt et al., 2015) } \\
\text { - Appropriate use of medication and treatment adherence (Krieger et al., } \\
\text { 2009; Marjolijn et al., 2016; Morrison et al., 2014) } \\
\text { - Increased disease and treatment knowledge (Marjolijn et al., 2016; Sattoe } \\
\text { et al., 2015) } \\
\text { - Decrease in depressive symptoms and patient perception of recovery } \\
\text { (Ludman et al., 2016) }\end{array}$ & $\begin{array}{l}\text { School nurses anecdotally reported: } \\
\text { - } \quad \text { Fewer/less severe exacerbations of } \\
\text { illness } \\
\text { - Improved school attendance } \\
\text { - Improved academic outcomes } \\
\text { - Improved perception of social } \\
\text { - } \text { relationships } \\
\text { - Hreater participation in life activities } \\
\text { - Improved confidence } \\
\text { - Improved self-advocacy } \\
\text { - Reduced fear of being "different" or } \\
\text { - } \text { "out of control" } \\
\text { - Fewer visits to the health office } \\
\text { - Increased understanding of condition } \\
\text { - Increased confidence responding to } \\
\text { - } \text { seizure warnings } \\
\text { - education plan and school stressors }\end{array}$ \\
\hline
\end{tabular}




\section{Figure 1}

Steps of hybrid concept analysis of self-management support in the context of school nursing
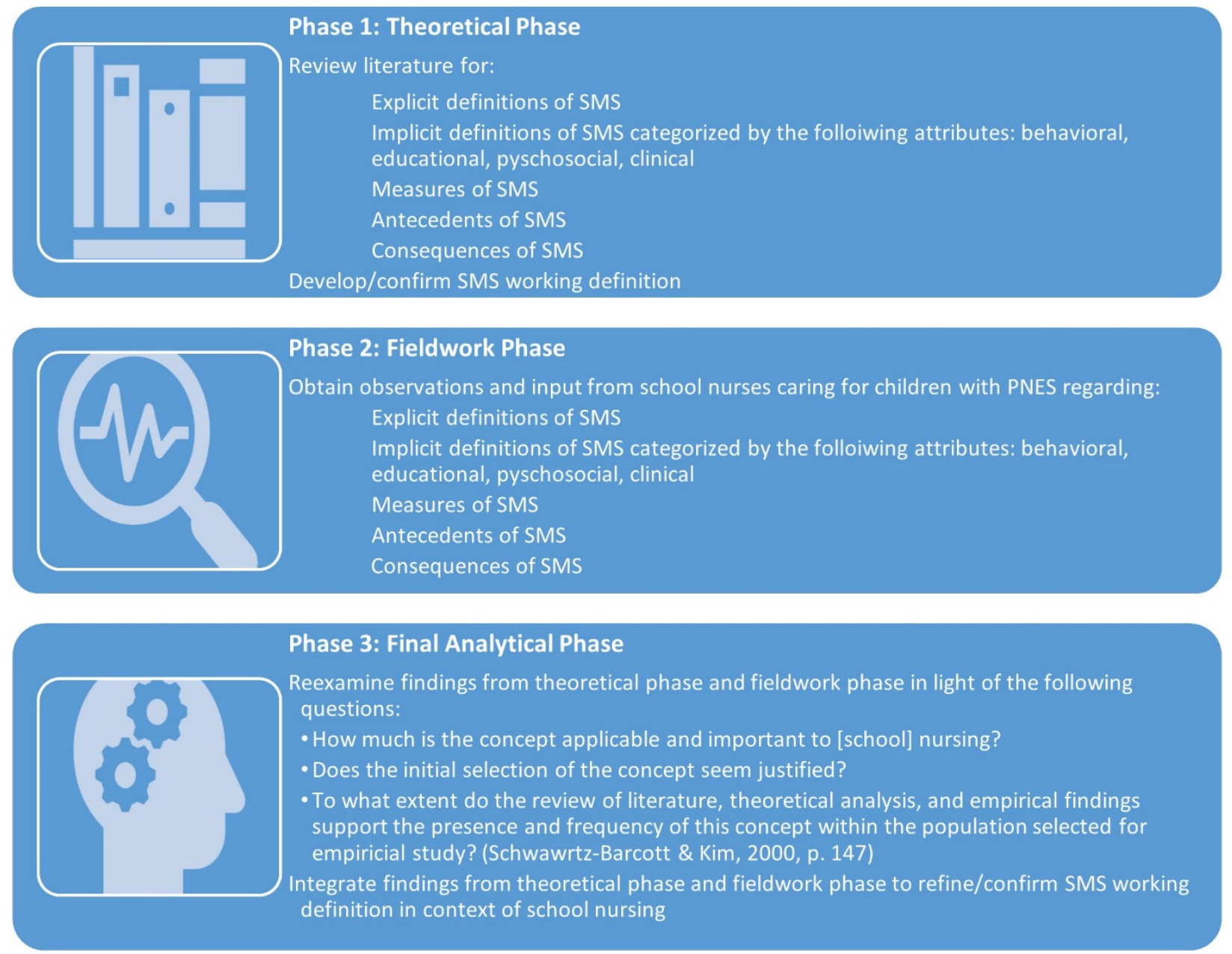

This is the author's manuscript of the work published in final edited form as:

Tanner, A., von Gaudecker, J., Buelow, J. \& Miller, W. Hybrid concept analysis of self-management support: School nurses supporting students with psychogenic nonepileptic seizures. Journal of School Nursing. 